Boise State University

ScholarWorks

Political Science Faculty Publications and

Presentations

Department of Political Science

9-1-2013

Does Patronage Matter? Connecting Influences on Judicial Appointments with Judicial Decision Making

Lori Hausegger

Boise State University

Troy Riddell

University of Guelph

Matthew Hennigar

Brock University 


\title{
Does Patronage Matter? Connecting Influences on Judicial Appointments with Judicial Decision Making
}

\author{
LORI HAUSEgGer Boise State University \\ TROY RIDDELL University of Guelph \\ MatThew HenNigar Brock University
}

In Canada, the federal government appoints judges to the superior trial courts and appellate courts in the provinces. While historically this power has not received the same media attention as the federal appointment power in the United States, the Canadian process has come under sustained scrutiny in recent decades. Indeed, following significant criticism in the early 1980s that the appointment process was unduly tainted by partisan considerations, the Conservative government created a new appointment process. This new process included the introduction of "screening committees" made up of various stakeholders (including legal representatives) who were responsible for vetting candidates.

However, scrutiny of the appointment process has continued and some suggest the changes have not had the desired effect. Various reports by academics, law societies and the media have suggested that party affiliation remains an important consideration in the new appointment process (see, for example, Hausegger et al., 2010; Meek, 1998; Schmitz, 2005). These reports also suggest that a new factor has become important in the appointment process: gender. This latest finding has been a matter of controversy, pleasing some observers who argue that the federal bench should be more representative and angering others who argue that an appointment should be based strictly on "merit." An additional

Lori Hausegger, Department of Political Science, Boise State University, 1910 University Dr., Boise ID 83725-1935 lorihausegger@boisestate.edu.

Troy Riddell, Department of Political Science, University of Guelph, Guelph, ON NIG2W1 riddell@uoguelph.ca.

Matthew Hennigar, Department of Political Science, Brock University, 500 Glenridge Ave., St. Catharines, ON L2S 3A1 matthew.hennigar@brocku.ca. 
controversy has sprung up surrounding the appointment process of Stephen Harper's Conservative government, which has promised to appoint more "law-and-order" judges. Some commentators suggest that the government is attempting to fulfill this promise in part by appointing more judges who were former Crown attorneys (Schmitz, 2007). However, while many are suggesting that partisan affiliation, gender and professional background may be influencing the appointment process, and some have called into question the fairness of such influences, little attention has been directed at determining whether it matters. Do different influences on the appointment process result in different decisions by the chosen judges?

In 2007, James Stribopoulos and Moin Yahya argued that a judge's gender and party of appointment can lead to different outcomes in certain kinds of cases decided by the Ontario Court of Appeal between 1990 and 2003. This suggests that these influences on judicial selection might matter. However, Stribopoulos and Yahya base their model on a large interaction term between all of their four variables of interest (case category, the decision below, party that appointed the judge and the judge's gender), which makes the separate influences difficult to determine. We also argue that "party of appointment" is not the most meaningful measure. Although many scholars, particularly those in the United States, use party of appointment as a surrogate for "policy preferences," this overlooks some important realities of the federal judicial appointment process in Canada. Governments tend to favour their own partisans in the selection process, but they also appoint a number of individuals who have no political background and occasionally appoint individuals who are connected to an opposition party. This suggests that if policy preferences influence the votes of these judges, party of appointment may not accurately measure it.

There are also varying degrees of party affiliation; presumably, a campaign manager might have stronger attachments to party policies than a person who makes the occasional donation to a party. We argue that party affiliation would be a more accurate measure of policy preferences than party of appointment and would also better map the Canadian judicial process by looking more closely at possible connections between selection processes and decision making.

After reviewing the relevant existing literatures on selection and decision making, we build on the database generously provided to us by Stribopoulos and Yahya and examine the influence of party affiliation, gender and professional background on decision making in the Ontario Court of Appeal between 1990 and 2003. In doing so, we hope to begin to address a number of issues in the existing literature, including the reliance on "party of appointment" as a proxy for policy preferences; the lack of attention paid to courts below the Supreme Court; the lack of attention 
Abstract. The federal government's power to appoint judges has come under increased scrutiny in recent years. While many suggest that partisan affiliation, gender and professional background may be influencing the Canadian appointment process, and some have called into question the fairness of such influences, little attention has been directed at determining whether these characteristics influence the outcome of cases. This paper studies decisions made by the Ontario Court of Appeal between 1990 and 2003 and uses a unique measure of partisan affiliation in an attempt to answer the question: do characteristics which play a role in the appointment process influence judicial decision making.

Résumé. Ces dernières années ont vu une augmentation de l'attention donné à l'autorité du gouvernement fédéral en ce qui concerne la nomination judiciaire. Il y en a plusieurs qui suggèrent que l'affiliation partisan, le sexe, et l'expérience professionnelle des candidats judiciaires sont tous des caractéristiques qui peuvent influencer la procédure de nomination. Encore d'autres ont remis en question l'équité d'un choix basé sur ces influences. Cependant, la question qui n'a pas reçu beaucoup d'attention jusqu'à maintenant est si ces caractéristiques influencent le résultat des affaires juridiques. L'article qui suit examine les décisions rendu par le Cour d'appel de l'Ontario entre les années 1990 et 2003, employant une mesure unique d'affiliation partisan, avec le but de répondre à la question : Est-ce que les caractéristiques qui peuvent jouer un rôle dans la procédure de nomination influencent les décisions judiciaires?

paid to whether professional background might influence judicial decision making; and, more generally, the tendency of the literature not to explicitly examine the possible connections between judicial selection and decision making.

\section{Judicial Process, Selection and Decision Making}

The question of judicial decision making in Canada has been assessed primarily by research on the Canadian Supreme Court (Flemming, 2004; Ostberg and Wetstein, 2007; Songer, 2008). Recently, some of this work has started to address the influence of gender on that court's decision making. In 2011, Johnson and her colleagues examined Supreme Court votes between 1982 and 2007 and concluded that female Supreme Court justices vote differently from their male counterparts in a variety of areas (see also Johnson and Songer, 2009). Female justices voted more liberally in equality, civil rights and private economic cases but more conservatively in criminal cases, a finding that was not dependent on the female justices reaching a critical mass on the court.

The focus on the Supreme Court is understandable given that court's position at the apex of the Canadian judicial hierarchy. However, the Canadian Supreme Court averages less than 100 decisions per year, which means that the provincial courts of appeal are the final courts of appeal for many cases in Canada. This in turn means that these courts play an important role in shaping the law. This is especially true of the Ontario Court of Appeal, which most years decides well over ten times as many cases as the Supreme Court (in 2004-2005, for instance, the OCA decided 
over 1,700 cases) and is often considered the most respected provincial appellate court. Indeed, this court has been referred to as the "junior Supreme Court" because of its doctrinal leadership (see Greene et al., 1998: 146). Unfortunately, these courts have not been subject to scholarly interest in their decision-making processes commensurate with their importance in the Canadian judicial process.

\subsection{Judicial process and selection}

The provincial appellate courts act as penultimate appellate courts below the Supreme Court, typically using three-judge panels. Each provincial appeal court has a wide jurisdiction and hears cases involving both provincial laws (encompassing everything from the environment to education to highways) and federal laws (including the Criminal Code of Canada). However, within their jurisdictions, these courts possess limited discretion over the cases they hear.

The judges making these decisions are appointed by the federal government. Individuals who apply for an appeal court position without any prior judicial experience, have their applications vetted by a screening committee composed of legal members, lay members and, more recently, a police officer. Candidates are evaluated on their professional qualifications (including awareness of racial and gender issues) and personal characteristics and then "recommended" or "not recommended" to the Minister of Justice who retains full discretion to choose among candidates. The majority of candidates are promoted from a lower court and do not go through the committee process at this stage. However, the minister typically undertakes consultations with the legal community before promoting someone (for a more detailed description of the appointment process, see Hausegger et al., 2010).

Our earlier research on federal judicial appointments following the introduction of the screening committees shows that for the 1989 to 2003 time period 27 per cent of provincial appeal court appointees had "major" participation with the governing party that appointed them (such as campaign organizing or close social ties to a cabinet minister), and 15 per cent had more "minor" activities and associations (political donations, minor constituency work) with the governing party. The trends were relatively consistent between Conservative and Liberal governments (see Hausegger et al., 2010, for a detailed description of all these data).

In addition to political affiliation playing a role in judicial selection to appellate courts, group identity, particularly gender, has become more of a consideration in the judicial appointments. The federal government in Canada made adding women to the bench more of a priority after the introduction of the screening committees. Approximately one-third of 
appointees to the provincial appellate courts from 1989 to 2003 were women (Riddell et al., 2008).

Overall, therefore, judicial appointment processes have resulted in Canadian provincial appellate courts that feature a number of individuals who were affiliated with the party in control of the executive branch prior to appointment. These processes have also placed an increasing number of women on these courts. The question raised is whether these patterns matter to case outcomes.

\subsection{Judicial decision making}

a) Party of appointing executive and policy preferences

Scholarship on decision making in Canadian courts of appeal is limited but there is a bourgeoning scholarship on decision making in US courts of appeal that can provide theoretical and empirical guidance. This work often uses quantitative models to address the question of whether political orientations or personal characteristics (such as gender, race or professional background) matter to case outcomes. Such models have been useful for demonstrating that the policy preferences of US federal courts of appeals judges matter at least somewhat to case outcomes in relatively predictable ways. Democratic judges are more likely to support the liberal position than Republican judges (Cross, 2007; Songer et al., 2000; Sunstein et al., 2004). Sunstein and his colleagues (2004), for example, used the ideology of the appointing president as a measure of the ideology of appellate justices and found that ideology was a statistically significant explanatory factor in such politically contested case categories as gay and lesbian rights, sex discrimination, labour and capital punishment. Judges appointed by a Democratic president voted for a more "liberal" outcome than their Republican-appointed counterparts. In a number of case categories, these individual ideological tendencies were either amplified or weakened depending on the ideology of the other panel members (319). The ideological dampening effect might be explained by collegiality. Colleagues' votes can "carry some information about what is right" (338).

\section{b) Gender}

In a 2010 study, Boyd and her colleagues found that female judges were significantly more likely to vote for the claimant in sex discrimination suits in the federal court of appeals between 1995 and 2002, even after including ideology as a control. They also found that men were 12 to 16 per cent more likely to vote in favour of the claimant if a woman was on the panel. Peresie (2005) found similar gender effects at the individual and panel level in a study of 556 sex discrimination and sexual harass- 
ment suits in federal courts between 1999 and 2001. Likewise, Farhang and Wawro's analysis (2004) of employment discrimination cases revealed that the presence of one female judge on the panel increased the probability of a male voting for the claimant by 19 per cent, though the addition of a subsequent female on the panel did not further increase the propensity of the male to vote for the claimant (320). They attribute the influence of a female presence to some combination of male judges being persuaded of a female viewpoint through deliberation and strategic calculations to achieve consensus (325).

However, with the exception of discrimination cases, the evidence is mixed about whether gender matters to judging on US federal courts of appeal (for an extensive review of previous work, see Boyd et al., 2010). Women judges in various criminal cases, for example, have been found to be more liberal (Cross, 2007), more conservative (Massie et al., 2002), or no different (Songer et al., 1994) from their male colleagues.

\section{c) Professional background}

In determining whether a judge's occupational background matters to decision making, the focus has tended to be on whether prior prosecutorial or defence counsel experience leads individuals to be more conservative or liberal, respectively. Controlling for other factors, Cross (2007) found that judges with previous experience in private practice were slightly more likely to make liberal decisions and former assistant district attorneys slightly more likely to make conservative decisions but being a former district attorney, US attorney, assistant US attorney or special prosecutor made no difference (84-85; see also work by Frank et al., 1987; Johnson, 2006; Sisk et al., 1998).

\section{d) Canadian studies}

In one of the rare studies of Canadian provincial courts of appeal, Greene and his colleagues (1998) interviewed close to 100 appellate judges between 1991 and 1995. Former Supreme Court Justice Bertha Wilson's assertion that female judges will make a difference to judicial decision making is noted (25), but no interview questions appear to have been asked about it. The authors do, however, note that ethnicity was not mentioned by a single judge as being related to case outcomes (33). Moreover, only a third of respondents said that their colleagues could be divided into ideological groups (77). The unusual access to judges given to Greene and his colleagues provides interesting information about the judges' own beliefs about their decision making but it does not test whether the judges' actual decision making was consistent with their description in interviews.

Stribopoulos and Yahya (2007) begin to fill this important gap. ${ }^{1}$ Using a database of over 4000 issues decided by the Ontario Court of Appeal 
between 1990 and 2003, they investigate whether gender or ideology (as measured by party of appointment), mattered to case outcomes. Cases are broken into large categories (such as criminal, family, corporate, private and human rights) and subcategories (for example, criminal includes subcategories such as offences against property and narcotics). The authors combined their variables of interest in one large interaction term and ran logits on the categories (full and subtype) to test for gender and ideological influence on individual voting and panel outcomes.

As one of the first studies in the area, the Stribopoulos and Yahya study appears to be mostly exploratory. The results are presented in such a way that makes summarizing difficult, but among the results highlighted by the authors are that individual Conservative appointees tended to favour the Crown over the accused slightly more than Liberals did in criminal cases (although this depended somewhat on the case category and which party appealed). As for gender on an individual-level basis, female judges were less likely to overturn an acquittal when the Crown appealed a case where the accused had successfully made a Charter of Rights challenge.

The Stribopoulos and Yahya project marks an important contribution to the study of appellate decision making in Canada providing detailed descriptive statistics on the cases and judges of the Ontario Court of Appeal and creating an extensive database which they use to test influences on decision making. Here we hope to build upon that foundation both methodologically and theoretically. Perhaps most importantly, we argue that using "party of appointment" as a proxy for ideology in Canada is less likely to produce valid results than in the US. The rate at which party affiliates are appointed to provincial courts of appeal is lower than the appointments of party affiliates to the US federal courts of appeal (Tarr, 2014: 67). Moreover, Canadian governments sometimes appoint opposition affiliates or individuals with no political background to provincial courts of appeal; indeed our previous work suggests only $42 \%$ of those appointed to the courts of appeal have either major or minor connections to the party appointing them (Hausegger et al., 2010). Not only might using "party of appointment" lead to a judge being mislabeled in the data set, but even when it does capture a judge's actual political affiliation correctly, its value might be limited. It does not tell us how active the individual was with a party, which may be an indicator of commitment to the party and its policies.

\section{Hypotheses and Measurement}

Our study attempts to understand the effect of a variety of judicial characteristics on our dependent variable: an individual judge's vote. We exam- 
ine the influences on this dependent variable in four case categories: criminal non-charter, criminal charter, family and human rights. The independent variables take into account the party affiliation, gender and professional background of the judges hearing a case, and control for the other factors thought to influence their decision making.

\section{a) Party affiliation}

Canadian political scientists have long debated whether federal political parties are organizations that consist of shifting coalitions of interests tied together through brokerage of regional, linguistic and cultural differences, or are organizations of ideologically like-minded people (Johnston, 1988). It appears that the answer lies somewhere in between. Ideology appears to play a role in structuring political attitudes in both the Liberal party and the former Progressive Conservative (PC) party, but both of those parties were less ideologically inclined than the NDP on the left and the former Reform/Canadian Alliance party on the right. In a 2000 survey of Canadian political party members, Young and Cross found that those who joined the Liberals or PCs did so more for social reasons, while those who joined the NDP and Canadian Alliance did so more for ideological reasons (2002). Nevertheless, PC respondents still placed themselves and their party to the right of the more centrist scores for Liberal respondents.

These results are promising for coding our PC affiliated judges as being more conservative in general than Liberal affiliates. However, since the judges we coded as "Conservative" partisans were all on the bench prior to the schism on the right, we need to examine potential ideological differences between PC and Liberal partisans before the creation of the Reform party in 1987 (which became the Canadian Alliance in 2000). A 1977 survey of six hundred elites in business, politics, law, bureaucracy, academia, labour and the media revealed that there were considerable differences between PC and Liberal supporters on social welfare/ redistribution and state economic intervention scales (Ornstein and Stevenson, 1984).

A survey administered to delegates at the 1983 PC national convention, and the 1984 Liberal national convention, showed divisions between the party delegates on issue scales related to such matters as support for social security (Liberal mean $=2.63$, PC mean $=1.67$ ), "hawkish" attitudes (Liberal mean $=2.65$, PC mean $=4.17)$ and anti-corporate power sentiments $($ Liberal mean $=1.98$, PC mean $=1.58)($ Blake, 1988: 40). From this, Donald Blake concludes that despite considerable variation within the parties on certain issues - and some of the relatively small differences between the parties on some issues - the "ideological model of interparty differences seems to have considerable support" (1988: 48). 
Johnston (1988) used a factor analysis of that same dataset collected at the conventions to evaluate whether delegates' political views in each party hung together in some coherent fashion. He argues that, although there was still sizeable unexplained variance, "ideological thinking pervaded each party's delegation" (1988: 60).

A 1987 survey on rights and democratic values suggests that Liberals might be somewhat more supportive of rights claims (Sniderman et al., 2000). The results showed that Liberal and PC party elites were both less supportive of rights than the NDP, but on a number of issues the PC elites are more "conservative" (less supportive of rights) than the Liberals. For instance, PC elites are more likely than Liberal elites to support banning sexually explicit acts in films, searching someone walking near a drug house and allowing customs officers to conduct a body search without a warrant (Sniderman et al., 2000: 576-78, 584).

Taken as a whole, we believe that the PC-affiliated judges will be more conservative on social and economic issues than Liberal affiliates. Therefore, we hypothesize that the stronger a judge's ties are to the Liberal party the more likely that judge is to vote for the accused in criminal cases, for women in family law cases and for the rights claimant in human rights cases. However, we expect these effects to be reasonably small, given that the differences between the parties on a number of issues, are not large.

We test our hypothesis using a measure of a judge's partisan ties. In previous work (Hausegger et al., 2010), we have used surveys and interviews of legal elites ${ }^{2}$ to determine the strength and direction of political ties for judges appointed by the federal government from 1989 to 2003. Judges are classified as having had minor political ties for activities such as donating to a political party or performing constituency work. Judges are classified as having had major political ties if they engaged in activities such as fundraising, organizing a campaign or running for office. They are also considered to have had major ties if they had a close social or professional relationship with someone who had a major direct involvement in the party such as a cabinet minister or an executive member (see Hausegger et al., 2010, for a detailed description of the data and the classifications). For this paper, we took those designations and created a measure of the direction and strength of a judge's tie. The variable ranges from -2 (major Conservative party ties) to +2 (major Liberal party ties); judges found to have no political ties were coded as 0 .

However, the US literature also suggests that institutional factors, such as collegial decision making, can serve to restrain the influence of ideological tendencies. Following Sunstein and his colleagues (2004), and Farhang and Wawro (2004), we test for these factors in our models of the influences on individual judge's votes. It may be that the effects of a judge's political ties are reduced by the presence of judges with oppos- 
ing ties on the panel. With three or five judges hearing a case, and the need for a majority vote, negotiations and compromises are often necessary. This level of appeals court also has a strong norm of unanimity, which increases the chances that judges may compromise with others and not vote their sincere political preference. To test for this phenomenon we include a variable measuring if a judge with Conservative party ties is sitting on a panel with someone with Liberal party ties, and a variable measuring whether a judge with Liberal party ties is sitting on a panel with someone with Conservative party ties.

\section{b) Gender}

Predicting the influence of gender on decision making is difficult. As suggested above, the empirical results are often contradictory even in the same area of law. Moreover, the theoretical explanations or predictions are often inadequate or missing. Implicitly or explicitly, however, expectations about women voting differently from men most often rely directly or indirectly on Carol Gilligan's suggestion (1982) that women's socialization leads them to develop an "ethic of care" that is different from a masculine perspective (Boyd et al., 2010; Gidengil et al., 2005; Malleson, 2003). More specifically, women are more likely to value relationships, consensus, inclusion and community in caring for others compared to the more individualistic, confrontational and competitive masculine outlook. Gilligan's work has been the subject of empirical and theoretical criticism, but as Beiner notes, the theory continues to be discussed and tested because "something about it rings true, or at least true based on some stereotyped notion of the way in which women behave" (2002: 602).

Recognizing that the underlying assumptions about why women may vote differently than men are contested and that translating these assumptions into actual predictions is difficult, for the purposes of this analysis we nevertheless make the following predictions. In criminal non-charter and criminal charter cases, female judges will be more likely to vote for the accused, who is often socially disadvantaged and is being threatened with criminal sanctions that are potentially isolating and stigmatizing. ${ }^{3}$

Since many rights cases (legislative and constitutional) advance arguments about protecting or providing benefits for the disadvantaged, we predict that female judges will be more likely to vote for rights claimants than male judges. In family law, female judges might be more able to identify with the perspective of the woman, and therefore, we predict that female judges will be more likely to support the female litigant's position, other things being equal. For each of the above categories gender is measured using a dummy variable (1 for a female judge, 0 otherwise).

Thus far we have framed gender predictions on an individual-level basis. However, recent research suggests that a judge's decision may be 
influenced by the gender of colleagues on the panel (Farhang and Wawro, 2004; Peresie, 2005). Consistent with the arguments made under partisan affiliation, we expect the norms of collegiality and unanimity to have an effect. Following Farhang and Wawro, we attempt to capture this possibility for gender in our models using independent variables measuring the presence of female colleagues on a panel. One variable measures whether a female judge has a female colleague on the panel, another variable measures a female colleague joining a male judge and a third variable measures whether more than one female colleague joins a male judge on a panel. We expect the addition of a female colleague will make a vote for the accused (in criminal cases), or the rights claimant (in human rights cases) or the female litigant (in family cases), more likely. We are also interested in whether adding multiple females to the panel increases this effect.

\section{c) Professional background}

Intuitively, one might suspect that experience as a prosecutor or government lawyer in rights cases would make a judge more likely to support the government in criminal and human rights cases respectively. Alternatively, a former defence lawyer might be more prone to be supportive of the accused in criminal cases. There is some limited empirical support for these propositions, so we include them in the model. Out of interest we also test whether prior experience as a government lawyer influences family law decisions. We have no strong expectation here, but government lawyer is a frequent prior occupation for judges and we want to explore its effect.

We determined a judge's former occupation using resources such as publicly available biographies. Some judges, of course, worked in multiple fields before coming to the bench. These judges were coded according to which was the dominant career in their past (for example, the career where they worked the longest).

\section{d) Other possible influences}

Research on intermediate courts of appeal highlights the importance of institutional context to judicial decision making. Scholars in the US have found that deference to lower courts and appellant-type are particularly consequential to the decisions made by the US courts of appeal. In Canada, research by Greene and his colleagues (1998; also see McCormick, 1993) suggests that the combined effect of these factors needs to be considered. For example, the Ontario Court of Appeal has a tendency to favour the Crown on criminal appeals. Greene and his colleagues speculate that this could be related to strict screening practices by the Crown on which 
cases to appeal. Therefore, we include in our model a variable measuring whether the Crown was the appellant in a criminal case. We expect the presence of the Crown as an appellant to make a vote for the accused less likely.

The Ontario Court of Appeal has a much higher rate of affirming in non-criminal cases. Therefore, we included in our model variables measuring the identity of the appellant in other case categories as well. We expect having a female litigant as the appellant in family law cases will make a decision in favour of the female litigant less likely, since the court is less likely to reverse overall. We have similar expectations for when the rights claimant is the appellant in human rights cases. The inclusion of these variables helps to control for the influence of the lower court's decision.

\section{The Models}

In this paper, multivariate models are used to determine the factors influencing the judicial decision making of the Ontario Court of Appeal from 1990 to 2003. The cases included are part of the database created by Stribopoulos and Yahya (2007), in which case participants and judge votes were coded for all reported cases of the court. ${ }^{4}$

While Stribopoulos and Yahya analyze the over 4900 case issues together through a large interaction term of all their variables (case category times the decision below times party appointing judge times gender of the judge), we prefer to run separate models for each case category. In this way we hope to create a more "natural experiment" (Farhang and Wawro, 2004) of a narrower issue area without the distraction of the wide variety of factual and legal issues that occur across case categories. This may be even more important for the Canadian courts of appeal given the wide range of issues they hear. We argue that large differences may exist, for example, between criminal non-charter cases and family law cases. The possibility of these differences suggests separate models may make it easier to distinguish the variety of influences on decision making and thus make systematic analysis of these influences more meaningful.

We ran models for four different case categories: (1) criminal noncharter (including, for example, narcotics and property crimes), (2) criminal charter, (3) family (primarily child and spousal support, and child custody), (4) human rights (non-criminal charter cases and human rights cases). The dependent variables are dichotomous in all the models: a vote in favour of the accused (criminal cases), the woman (family), the rights claimant (human rights), or not. Therefore, logit models were estimated.

The independent variables of interest include the judge's gender, the strength and direction of his or her party affiliation, the judge's past pro- 
fessional experience ${ }^{5}$ and the appellant in the case. ${ }^{6}$ This latter measure functioned as a control for the Crown's high success rate in criminal cases, and as a control for the court's slight propensity to affirm cases in the other issue areas. $^{7}$

However, Courts of Appeal hear cases in panels of three or five judges, and as argued above, the need to reach a majority vote means judges may influence one another through negotiation and compromise. To account for this institutional characteristic we also included variables in the models measuring the presence of female colleagues on a panel and the presence of colleagues of opposing party affiliation. Following Farhang and Wawro (2004), for gender we included a variable measuring if a female judge has a female colleague on the panel, another measuring a female colleague joining a male judge and a third variable measuring whether more than one female colleague joined a male judge on a panel. For party affiliation we included a variable measuring whether a Liberal-affiliated judge is on a panel with a colleague with ties to the Progressive Conservative party and a variable measuring whether a PC-affiliated judge was joined by a colleague with Liberal ties.

As discussed above, our measure of "party affiliation" comes out of our previous research on judicial selection (Hausegger et al., 2010), and we argue that it more accurately captures the judge's connection to a party and its policies (and thus better approximates a judge's policy preferences) than a measure of "party of appointing prime minister." Our interest in this measure led us to also estimate each case category model of individual judge vote with party of appointing prime minister as a variable to compare results. In this estimate we attempted to capture the influence of colleagues through variables measuring if a Progressive Conservative-appointed judge was on a panel with Liberal appointees and whether a Liberal-appointed judge was on a panel with PC appointees.

\section{Results}

Tables 2 to 5 show the results of the logit analyses of the variables hypothesized to influence the votes of judges on the Ontario Court of Appeal in each of our four case categories. Table 1 summarizes the results for our variables of interest. For each case category, a "yes" next to a variable indicates that it performed in the expected direction and is significant at the 0.05 level or better (unless otherwise noted on the table).

\section{a) Party affiliation}

Tables 2 and 3 suggest that party affiliation had some influence on a judge's vote in criminal non-charter and criminal charter case issues. A 


\section{TABLE 1}

Summary of Variable Results from Logit Analysis, Individual Judge Vote as DV ("Yes Indicates Significant in Expected Direction)

\begin{tabular}{lcccc}
\hline \hline & $\begin{array}{c}\text { Criminal } \\
\text { NonCharter }\end{array}$ & $\begin{array}{c}\text { Criminal } \\
\text { Charter }\end{array}$ & Family & HumanRts \\
\hline $\begin{array}{l}\text { Gender } \\
\begin{array}{l}\text { Female judge with another } \\
\text { female }\end{array}\end{array}$ & Yes & No & Yes & Yes \\
$\begin{array}{l}\text { Male judge with 1 female } \\
\text { judge }\end{array}$ & Yes & No & No & No \\
$\begin{array}{l}\text { Male judge with multiple } \\
\text { females }\end{array}$ & No & No & No & $\begin{array}{c}\text { Yes } \\
\text { (at .06) }\end{array}$ \\
$\begin{array}{l}\text { Party ties } \\
\begin{array}{l}\text { Judge with Conservative ties } \\
\text { on panel with at least one }\end{array}\end{array}$ & Yes & No & No & No \\
judge with Liberal ties & Yes & No & No \\
$\begin{array}{l}\text { Judge with Liberal } \\
\text { ties on panel with } \\
\text { at least one judge } \\
\text { with Conservative ties }\end{array}$ & Yes & No & No & Yes \\
$\begin{array}{l}\text { Past Crown or government } \\
\text { attorney }\end{array}$ & No & Yes & Yes & No \\
$\begin{array}{l}\text { Past defense } \\
\text { Crown or woman or rts } \\
\text { claimant (depending on } \\
\text { case type) as appellant }\end{array}$ & Yo level) & & \\
\hline
\end{tabular}

vote for the accused was more likely the stronger the judge's Liberal party ties $(\mathrm{p}<.001)$. Indeed, a judge with major Liberal party ties was 21 per cent more likely to vote for the accused in a criminal charter case than a judge with major Progressive Conservative party ties (see Table 6 for the probability change of significant variables). However, both these models suggest that judges with Liberal ties were less likely to vote for the accused when judges with Progressive Conservative ties sat on a panel with them $(\mathrm{p}=.001$ and $\mathrm{p}=.06)$. Thus there is evidence in these case categories that a judge's colleagues can influence their vote. This is consistent with the ideological dampening effect of panels discussed earlier.

A judge's own party ties does not appear to have influenced his or her vote in family or human rights case issues, but sitting on a panel with those that had such ties does appear to have had an effect. A vote for the woman in a family law case issue, such as child custody or spousal support was 19 per cent less likely from a judge with Liberal ties if he or she sat on a panel with a judge with PC ties $(\mathrm{p}<.01)$.

In human rights issues, a vote for the rights claimant was 23 per cent more likely from a judge with PC party ties when he or she was 


\section{TABLE 2}

Logit Analysis of Hypothesized Determinants of Judge Votes for Accused in Criminal Non Charter Cases, Ont CT of Appeal, 1990-2003

\begin{tabular}{|c|c|c|c|c|c|c|}
\hline \multirow[b]{2}{*}{ Variable } & \multicolumn{3}{|c|}{ Model 1} & \multicolumn{3}{|c|}{ Model 2} \\
\hline & B & SE & Sig.* & B & SE & Sig* \\
\hline Constant & -0.505 & 0.067 & & -0.422 & 0.125 & \\
\hline Gender & 0.188 & 0.113 & 0.049 & 0.199 & 0.115 & 0.042 \\
\hline Fem + Fem Collgue & -0.188 & 0.157 & 0.232 & -0.222 & 0.157 & 0.156 \\
\hline Male +Fem Collgue & 0.154 & 0.087 & 0.038 & 0.143 & 0.086 & 0.049 \\
\hline Male+Multi Fem & -0.079 & 0.188 & 0.676 & -0.111 & 0.187 & 0.553 \\
\hline Party Ties & 0.143 & 0.044 & 0.001 & - & - & - \\
\hline Con Ties wth Libs & -0.074 & 0.147 & 0.616 & - & - & - \\
\hline Lib Ties with Cons & -0.432 & 0.128 & 0.001 & - & - & - \\
\hline PtyofAppt & - & - & - & 0.003 & 0.140 & 0.490 \\
\hline Con Appt wth Libs & - & - & - & -0.215 & 0.125 & 0.087 \\
\hline Lib Appt wth Cons & - & - & - & -0.133 & 0.104 & 0.102 \\
\hline Crown Exper & -0.075 & 0.207 & 0.359 & -0.075 & 0.210 & 0.361 \\
\hline Def Exper & 0.022 & 0.085 & 0.396 & 0.090 & 0.088 & 0.154 \\
\hline GovtAsAppell & -0.487 & 0.113 & 0.000 & -0.472 & 0.112 & 0.000 \\
\hline
\end{tabular}

*Level of statistical significance - coefficients significant at the .05 level or better are shown in bold. Based on one-tailed tests for variables in the expected direction.

\begin{tabular}{lcc}
\hline & Model 1 $(\mathbf{N}=\mathbf{3 2 9 3})$ & Model 2 $(\mathbf{N}=\mathbf{3 2 9 3})$ \\
\hline Initial log likelihood & -2173.94 & -2205.86 \\
Final log likelihood & -2149.51 & -2189.43 \\
Chi square of the model & $48.86(10 \mathrm{df}$; sig. $=0.000)$ & $32.86(10 \mathrm{df}$, sig. $=0.000)$ \\
\hline
\end{tabular}

sitting on a panel with someone with Liberal party ties $(\mathrm{p}<.05)$. This result is interesting as it only appears in the human rights area; judges with PC party ties do not behave significantly differently in any other issue area when on a panel with a judge with Liberal ties. By contrast, judges with Liberal party ties appear to be influenced by their PC colleagues across more issue areas. These results were unexpected and suggest a need for further examination. There were more judges with Liberal ties sitting on the Ontario Court of Appeal in our time period, but the differences are not extreme (for example, in criminal non-charter cases, 32 per cent of the judges had some Liberal party ties, while 20 per cent had some PC party ties).

Although we can only speculate, if Liberal affiliates have a less structured set of ideological commitments, then perhaps they are more easily persuaded than are Progressive Conservative affiliates. Whether seen as a virtue or a vice, the Liberal party is known in Canadian politics for its 


\section{TABLE 3}

Logit Analysis of Hypothesized Determinants of Judge Votes for Accused in Criminal Charter Cases, Ont CT Appeal, 1990-2003

\begin{tabular}{|c|c|c|c|c|c|c|}
\hline \multirow[b]{2}{*}{ Variable } & \multicolumn{3}{|c|}{ Model 1} & \multicolumn{3}{|c|}{ Model 2} \\
\hline & B & SE & Sig.* & B & SE & Sig* \\
\hline Constant & -1.166 & 0.145 & & -0.779 & 0.276 & \\
\hline Gender & 0.016 & 0.250 & 0.475 & 0.184 & 0.259 & 0.238 \\
\hline Fem + Fem Collgue & -0.265 & 0.388 & 0.494 & -0.147 & 0.391 & 0.708 \\
\hline Male+Fem Collgue & 0.137 & 0.183 & 0.227 & 0.119 & 0.187 & 0.262 \\
\hline Male + Multi Fem & -0.380 & 0.474 & 0.423 & -0.331 & 0.480 & 0.490 \\
\hline Party Ties & 0.282 & 0.100 & 0.003 & - & - & - \\
\hline Con Ties wth Libs & 0.303 & 0.330 & 0.179 & - & - & - \\
\hline Lib Ties with Cons & -0.438 & 0.286 & 0.063 & - & - & - \\
\hline PtyofAppt & - & - & - & -1.177 & 0.347 & $0.001+$ \\
\hline Con Appt with Libs & - & - & - & -0.531 & 0.264 & $0.044+$ \\
\hline Lib Appt with Cons & - & - & - & -1.071 & 0.287 & $0.000+$ \\
\hline Crown Exper & 0.422 & 0.456 & 0.355 & 0.185 & 0.476 & 0.697 \\
\hline Def Exper & 0.391 & 0.174 & 0.013 & 0.506 & 0.182 & 0.003 \\
\hline GovtAsAppell & -0.130 & 0.182 & 0.238 & -0.241 & 0.182 & 0.094 \\
\hline
\end{tabular}

*Level of statistical significance: coefficients significant at the .05 level or better are shown in bold. Based on one-tailed tests for variables in the expected direction.

+ Variable results in unexpected direction

\begin{tabular}{lcc}
\hline & Model $\mathbf{1}(\mathbf{N}=\mathbf{8 6 0})$ & Model 2 $(\mathbf{N}=\mathbf{8 6 5})$ \\
\hline Initial log likelihood & -498.39 & -500.95 \\
Final log likelihood & -488.78 & -485.61 \\
Chi square of the model & $19.22(10 \mathrm{df}$; sig. $=0.038)$ & $30.68(10 \mathrm{df}$, sig. $=0.001)$
\end{tabular}

ideological pragmatism. Some social science research bears out this perception. In his factor analysis of surveys completed by party delegates of both parties, for example, Johnston found that the PCs were a more divided party because their divisions were "more structured" and "more relentlessly cumulative" (1988: 65). He also noted that "if the Liberal left was soft, the Tory right was pretty hard" (64).

As illustrated in model 2 of Tables 2 to 5, our party ties measures show significant results in the expected direction more often than measures based on party of appointment. The only exception is in family law cases. The lack of significance of the party ties variable likely reflects the less clear differences between the two parties in this issue area which would lead to less predictable distinctions between appointees with strong Liberal ties and those with strong PC ties. Since the party of appointment measure captures more than appointees who are connected to the party and its policies, its significant performance in family cases might be the result of some other unexplored factor. 
TABLE 4

Logit Analysis of Hypothesized Determinants of Judge Votes for Wife/Mother in Family Law Cases, Ont CT Appeal, 1990-2003

\begin{tabular}{|c|c|c|c|c|c|c|}
\hline \multirow[b]{2}{*}{ Variable } & \multicolumn{3}{|c|}{ Model 1} & \multicolumn{3}{|c|}{ Model 2} \\
\hline & B & SE & Sig.* & B & SE & Sig* \\
\hline Constant & 0.662 & 0.161 & & -0.876 & 0.336 & \\
\hline Gender & 0.584 & 0.303 & 0.027 & 0.646 & 0.311 & 0.019 \\
\hline Fem + Fem Collgue & -0.326 & 0.401 & 0.417 & -0.119 & 0.408 & 0.771 \\
\hline Male + Fem Collgue & 0.208 & 0.219 & 0.171 & 0.211 & 0.222 & 0.171 \\
\hline Male + Multi Fem & 0.360 & 0.435 & 0.204 & 0.533 & 0.456 & 0.122 \\
\hline Party Ties & 0.084 & 0.120 & 0.243 & - & - & - \\
\hline Con Ties wth Libs & -0.202 & 0.389 & 0.604 & - & - & - \\
\hline Lib Ties with Cons & -0.782 & 0.303 & 0.005 & - & - & - \\
\hline PtyofAppt & - & - & - & 1.752 & 0.360 & 0.000 \\
\hline Con Appt with Libs & - & - & - & 1.594 & 0.350 & 0.000 \\
\hline Lib Appt wth Cons & - & - & - & -0.197 & 0.253 & 0.218 \\
\hline Govt Exper & -0.995 & 0.491 & 0.043 & -1.256 & 0.440 & 0.004 \\
\hline FemAsAppell & -0.553 & 0.185 & 0.002 & -0.629 & 0.189 & 0.001 \\
\hline
\end{tabular}

*Level of statistical significance: coefficients significant at the .05 level or better are shown in bold. Based on one-tailed tests for variables in the expected direction.

\begin{tabular}{lcc}
\hline & Model 1 $(\mathbf{N}=\mathbf{5 4 5})$ & Model 2 $(\mathbf{N}=\mathbf{5 4 8})$ \\
\hline Initial log likelihood & -362.83 & -364.76 \\
Final log likelihood & -349.50 & -340.30 \\
Chi square of the model & $26.66(9 \mathrm{df} ;$ sig. $=0.002)$ & $48.92(9 \mathrm{df}$, sig. $=0.000)$
\end{tabular}

Outside the family law area, party of appointment does not perform well. A vote for the accused is not more likely from a Liberal party appointment in criminal non-charter cases and a vote for the accused is actually less likely from a Liberal appointment in criminal charter cases. Indeed, for criminal charter cases, all three variables based on party of appointment are significant in the unexpected direction. Judges appointed by the Liberal party are also less likely to support rights claimants (in human rights case issues), contrary to expectations.

The number of results in the unexpected direction for party of appointment (results that are hard to explain) is an important finding. The results cast doubt on the accuracy of the measure and suggest the difficulties of using the party of appointment for judges when predicting their votes. Included in this study are judges with major political ties to the Liberal party, who were appointed to the Ontario Court of Appeal by the Progressive Conservative party, and the reverse holds true as well. We believe these judges are more likely to be influenced by the party with which they had significant political ties, than the party that appointed them to the Court of Appeal. ${ }^{8}$ 


\section{TABLE 5}

Logit Analysis of Hypothesized Determinants of Judge Votes for Rights Claimant in Human Rights Cases, Ont CT Appeals, 1990-2003

\begin{tabular}{|c|c|c|c|c|c|c|}
\hline \multirow[b]{2}{*}{ Variable } & \multicolumn{3}{|c|}{ Model 1} & \multicolumn{3}{|c|}{ Model 2} \\
\hline & B & SE & Sig.* & B & SE & Sig* \\
\hline Constant & -0.374 & 0.315 & & 0.937 & 0.524 & \\
\hline Gender & 0.798 & 0.414 & $\mathbf{0 . 0 2 7}$ & 0.661 & 0.414 & 0.055 \\
\hline Fem + Fem Collgue & 0.125 & 0.644 & 0.423 & 0.288 & 0.667 & 0.333 \\
\hline Male+Fem Collgue & 0.522 & 0.344 & 0.065 & 0.427 & 0.348 & 0.110 \\
\hline Male+Multi Fem & 0.552 & 0.936 & 0.278 & 0.766 & 0.922 & 0.203 \\
\hline Party Ties & 0.189 & 0.167 & 0.129 & - & - & - \\
\hline Con Ties with Libs & 0.981 & 0.548 & 0.037 & - & - & - \\
\hline Lib Ties with Cons & 0.247 & 0.415 & 0.551 & - & - & - \\
\hline PtyofAppt & - & - & - & -1.248 & 0.539 & $0.021+$ \\
\hline Con Appt with Libs & - & - & - & -1.025 & 0.502 & $0.041+$ \\
\hline Lib Appt with Cons & - & - & - & 0.030 & 0.387 & 0.939 \\
\hline Govt Exper & -2.097 & 1.106 & 0.029 & -2.132 & 1.073 & 0.024 \\
\hline RtsClaimAppell & -1.218 & 0.305 & 0.000 & -1.238 & 0.308 & 0.000 \\
\hline
\end{tabular}

*Level of statistical significance - coefficients significant at the .05 level or better are shown in bold. Based on one-tailed tests for variables in the expected direction.

+ Variable results in unexpected direction

\begin{tabular}{lcc}
\hline & Model 1 $(\mathbf{N}=\mathbf{2 7 1})$ & Model 2 $(\mathbf{N}=\mathbf{2 7 2})$ \\
\hline Initial Log Likelihood & -174.93 & -175.35 \\
Final Log Likelihood & -158.11 & -156.86 \\
Chi Square of the Model & $33.64(9 \mathrm{df}$; sig. $=0.000)$ & $36.99(9 \mathrm{df}$, sig. $=0.000)$ \\
\hline
\end{tabular}

\section{b) Gender}

The gender of the judge also appears to have influenced a judge's vote in various issue areas. A vote for the accused was more likely from a female judge in criminal non-charter case issues $(\mathrm{p}<.05)$. In addition, consistent with our hypotheses, a vote for the woman litigant was more likely from a female judge in family law case issues, and a vote for the rights claimant was more likely from a female judge in human rights case issues ( $\mathrm{p}<.05$ for both). Indeed, female justices were 18 per cent more likely to support the rights claimant than their male colleagues.

The influence of colleagues is less clear with regard to gender. ${ }^{9}$ Adding a second female to the bench does not appear to affect a female judge's vote in any of our case issues. However, a vote for the accused was more likely from male judges when they were on a panel with a female judge $(\mathrm{p}<.05)$ in criminal non-charter cases, although the 4 per cent difference is small. Male judges also appear to be influenced by the presence of a female judge in human rights case issues (but only at the .06 level). A 
TABLE 6

Probability Change of Voting for Accused/Woman/Rights Claimant, between the Min and Max Values for Sig Variables**

\begin{tabular}{lcccc}
\hline \hline & $\begin{array}{c}\text { Criminal } \\
\text { NonCharter }\end{array}$ & $\begin{array}{c}\text { Criminal } \\
\text { Charter }\end{array}$ & Family & HumanRts \\
\hline $\begin{array}{l}\text { Gender }(0 \text { male, } 1 \text { = female) } \\
\text { Male judge with 1 female judge }(0,1)\end{array}$ & $5 \%$ & - & $13 \%$ & $18 \%$ \\
$\begin{array}{l}\text { Party ties (-2 Strong Conservative } \\
\quad+2 \text { Strong Liberal) }\end{array}$ & $13 \%$ & - & - & $11 \%$ \\
$\begin{array}{l}\text { Judge with Conservative ties on } \\
\text { panel with at least one judge } \\
\quad \text { with Liberal ties }(0,1)\end{array}$ & - & - & - & - \\
$\begin{array}{l}\text { Judge with Liberal ties on panel } \\
\quad \text { with at least one judge with }\end{array}$ & $-10 \%$ & $-7 \%$ & $-19 \%$ & - \\
$\quad \begin{array}{l}\text { Conservative ties }(0,1) \\
\text { Past Crown or government } \\
\quad \text { attorney }(0,1)\end{array}$ & - & - & $-24 \%$ & $-25 \%$ \\
\begin{tabular}{l} 
Past defense $(0.1)$ \\
\hline
\end{tabular} & - & $8 \%$ & N/A & N/A \\
\hline
\end{tabular}

**The probability change was constructed by placing all variables at their mean value and moving the variable of interest from its minimum to its maximum value.

vote for the accused in the criminal case category is not more likely from a male judge if there is more than one female on the panel and this result is consistent across all the other issue areas as well. Farhang and Wawro (2004) had a similar finding in their study of the US Courts of Appeal. The addition of more than one female does not increase the probability of a male judge voting in a particular direction; the effect appears to be created by the addition of the first female. Overall, the influence of colleagues appears more consistent when examining partisan ties, than when examining gender.

\section{c) Professional background}

Tables 2 to 5 indicate that the professional background of a judge has influence in a few of the issue areas. In criminal charter cases, a vote for the accused was more likely by judges who had defence work in their background $(\mathrm{p}<.05)$. However, this result did not hold in criminal noncharter cases. Perhaps the same influences are not working in these cases that lack civil liberties claims, and even former defence attorneys view these accused less favourably.

While we expected former Crown attorneys to be less likely to support the accused in criminal cases, this variable did not reach statistical significance in any of the models. This result is perhaps not surprising given the low number of Crown attorneys on the Ontario Court of Appeal 
during our time frame. It may be that the influence would be more visible with more Crowns on the bench. Alternatively, it may mean that those who argue Prime Minister Harper is putting more former Crowns on the bench in an effort to appoint more law-and-order judges, have little to fear. Those already on the Ontario Court of Appeal are not voting for the accused in a significantly different way than judges from other professions. We will need to include more years and courts in the model - and thus more judges and more Crown attorneys - to determine which of these alternatives is correct.

As discussed above, the possible deliberate appointment of former Crowns to the bench increased our interest in the professional background of judges. We decided to explore this factor beyond the criminal area. Thus, in other case categories we include a variable measuring another frequent former profession of judges: government attorney (working outside the criminal area). This variable performs as we expected in the human rights area: former government attorneys are 25 per cent less likely to vote in favour of the rights claimant $(p<.05)$. Since their former career may have involved defending the government in court, these judges may be more sympathetic to the government's position and less inclined to support a rights claimant challenging a government entity.

As we stated, we did not have expectations for how former government attorneys would vote differently in family case issues. ${ }^{10}$ The results of the model suggest that a former government attorney is less likely to support the female litigant in family law cases $(p<.05)$. We do not have a ready explanation for this result. However, in future work we intend to explore both it and the influence of other professional backgrounds on the votes of judges.

\section{d) Appellant}

The scholarly literature in both the United States and Canada suggested a control for another potential influence on judges' votes: the Crown as appellant in criminal cases. For other types of case categories we also included a control variable measuring the identity of the appellant. These variables performed as expected in all the case categories we tested them in.

\section{Discussion}

Our results have shown that party affiliation and gender matter to individual judicial voting behaviour in various types of cases. For example, judges with Liberal ties are more likely to vote for the accused in criminal cases, and women are more likely to vote for the rights claimant in human rights cases. However, we found that judges' voting behaviour 
may vary when an individual with different party ties or gender characteristics joins them on a panel. What do these findings for the Ontario Court of Appeal mean for key areas of judicial process, particularly selection and decision making processes? Answering this question implicates various normative and empirical issues about the role of law and courts in the larger system of governance.

In the US, some commentators have used such results to argue that decision-making panels in the federal courts of appeal should be mixed in terms of their political and gender make-up. Stribopoulos and Yahya make a similar claim in Canada, arguing that "diversity in the political and gender mix of appellate court panels is essential." They suggest that the registrar of the court who assigns judges to hear cases could develop a process to ensure such diversity on panels. This seems like a straightforward proposal, but many complications arise on closer inspection. Since we argue that political affiliation is a more accurate predictor than party of appointment, determining the political mix on a panel would require knowledge of a judge's connections to a party and party officials. In terms of gender, how would the registrar know which particular women on the court reflected the "ethic of care" in their decisions and which ones did not? (And what about males who might hold stereotypes about women that led them to be subconsciously biased in favour of the woman in family law cases?) Would the judicial selection system have to be changed such that enough female appointees who did exhibit the ethic of care and enough partisans of various stripes were selected to each appellate court to allow for balanced panels to be created?

Those who view the law as reasonably determinate and who desire the courts to primarily be "adjudicators of legal disputes" within the political system would argue that there should be no consideration of party ties or gender in the judicial selection process. The process should emphasize legal professionalism (knowledge of case law and so on) above all else. At the federal level, this might necessitate the creation of a nomination committee system where legal members and lay people recommend the three most qualified applicants for a judicial opening and the Minister of Justice must choose one of those individuals for the appointment. Individuals wanting appointments to the appellate court from the trial court would also need to go through this process. According to this view, courts will make policy interstitially when deciding some cases and some minor variations in decision making will result from personalities, but the emphasis on "the law" would mitigate political considerations (partisan, gender, ethnicity and so on) in both appointments and decision making.

Alternatively, those who value the courts as "policy makers" (whether because the courts are perceived to be more accessible to minority groups or able to push politicians on sensitive issues), or simply believe that the 
law is relatively more indeterminate and socially constructed, would welcome certain political considerations in the judicial appointment process, such as gender and ethnicity. What a supporter of the "adjudicative model" might see as "bias" in decision making, is seen by this view as bringing a valuable perspective to the development of the law (Malleson, 2003). ${ }^{11}$

Although these two "ideal types" of law and courts - the adjudicative model and the policy making model-help us to structure our thinking about the relationship between judicial selection, decision making and the role of courts in the governing process, there are complexities to those relationships not adequately captured above. First, it is likely that whether someone supports the inclusion of political considerations in the judicial selection process depends on what those political considerations are (for example, the appointment of law-and-order judges versus the appointment of "progressive" judges). Second, some people argue for an altered judicial appointment system, such as reducing the importance of political patronage and appointing more minorities, for reasons of fairness and legitimacy not connected to decision-making outcomes. Third, the institutional context of intermediate courts of appeal lends itself to both the "adjudicative" and "policy-making" styles of decision making. Some institutional factors associated with the policy-making model include the leadership role that such courts provide in contested areas of the law and the rare chance that their decisions will be reviewed by the Supreme Court. Furthermore, some case types decided by the appellate courts allow for the influence of non-legal factors and have considerable policy ramifications. This is particularly true in rights cases. Perhaps it is not surprising, therefore, that we find considerable support for our hypotheses in these areas of the law. For example, a female judge is 18 per cent more likely to favour the rights claimant in human rights cases.

These results may prompt some to consider changes in the judicial appointment system and how judges are placed on panels. However, there is also the reality that intermediate appellate courts are forced to hear a number of routine cases that are easily disposed of by the law, that there is a high rate of unanimity on such courts and that courts like the Ontario Court of Appeal are not the final court of appeal. Just as it might not be surprising that we had significant results in rights cases, it may not be surprising that in other case areas our statistical measures prove to be weak or not significant.

\section{Conclusion}

Different influences on the appointment process may in fact result in different decisions by the chosen judges. Our findings suggest that judges 
appointed as a result of their political ties or their gender may vote differently on some case issues. A judge's past profession may also have an influence on their decision making once on the bench. Thus, it might make a difference if Prime Minister Harper concentrates on appointing former Crowns to the bench. And it should definitely make a difference if he focuses on the political affiliation of appointees. Initial research into the Harper appointments suggests that the Harper government is appointing party affiliates at roughly the same rate as previous governments. However, as his Conservative government is an amalgam of the former PC party and the more right-wing Canadian Alliance party the political affiliates chosen by Harper may be more conservative than previous appointments. This may in turn make a difference to the outcome of cases in some areas of law. This will be particularly true if Harper is deliberately appointing judges on the basis of policy preferences, as he appears to be doing with his promise to appoint more law-and-order judges.

Regardless of whether one sees the influence of judicial characteristics as beneficial or harmful to judicial decision making, there is much left to be done before one argues for or against changes in the judicial selection process. First, while we believe our measure of party affiliation captures influence more accurately than party of appointing prime minister, a more sophisticated measure of ideology for judges on courts below the Supreme Court still needs to be developed. Such a measure will need to be cognizant that historically, appointment of party affiliates has tended to be based more on patronage than policy preferences. Thus ideological differences appear more as a by-product of party affiliation rather than by deliberate design. For the time being, at least, Harper is the only prime minister who has seemingly paid much attention to the ideological make-up of the judiciary.

Not only do we need to think more carefully about ideology and its relationship to party, we also need to better theorize and test gender influences. For example, to better test whether women judges are more sympathetic to victims and underdogs, it might be useful to compare the gender results in criminal cases involving offences against the person and criminal cases involving offences against property.

Finally, we need to test our theories and measures, across time, and across appellate courts. The Ontario Court of Appeal is the preeminent court of appeal in Canada. It will be useful to discuss whether the same influences are at work elsewhere on courts that receive less attention. Previous work has also found that our measure of partisan ties might differ across the country. Judges sitting on courts in the Atlantic provinces are much more likely to have major political ties than judges sitting on courts in British Columbia. Thus the next step of researchers in this area should be to test these measures, and other improved ones, on provincial courts of appeal across Canada. 


\section{Notes}

1 Peter McCormick has presented extensive research on decisions in the Alberta and Manitoba courts of appeal in particular, but he does not use quantitative modeling to test for effects.

2 Legal elites included law professors with more than ten years experience and prominent senior lawyers. The latter category included lawyers who had held positions in provincial law societies and the Canadian Bar Association as well as lawyers designated as Queen's Counsel. We supplemented the legal elite information through interviews with senior party officials and senior government officials involved in judicial selection.

3 This study does not include criminal cases with a gender component, such as sexual assault, as such cases may cloud the analysis. Female judges might be expected to view such gender specific cases differently from other criminal cases.

4 The Stribopoulos and Yahya data had a distinct case issue for each row entry and five columns of judge vote for the five possible positions on a panel. After creating all the case-specific variables we flipped the data so that judge vote became the dependent variable with each row representing a different judge's vote on an issue. The data included cases decided by both three- and five-judge panels and we include both in our models. Following the practice of some of the court of appeal literature in the United States, we also ran the models excluding panels of five. This did not have a significant effect on our results (the performance of our variables of interest remained consistent), and without a strong reason to exclude these en banc panels, we preferred to use all the data.

5 This variable differs by case category. For criminal cases one variable measures whether the judge was a past Crown while another measures if he or she was a past defence attorney. For all other cases, one variable measures whether a judge was a past government attorney.

6 This variable also differs by case category. For criminal cases it measures the presence of the Crown as the appellant in the case. For family law it measures if the woman was the appellant. For human rights cases it determines if the rights claimant was the appellant.

7 For our time period, the Ontario Court of Appeal affirmed 59 per cent of all family law cases and 69 per cent of human rights cases.

8 This should be particularly true for the judges who have been appointed to the Trial Court by one party and appointed to the Court of Appeal by a different party, a not infrequent event.

9 We ran the models again without the measures of colleagues' gender in order to test the influence of gender alone. We also ran this model (and the others) with just one of the colleagues' gender measures. The results were consistent across all the models, with the same variables of interest remaining significant.

10 With no expectation for this variable in this case category, we also ran the model excluding it from the analysis. This did not affect the results of the model; the same variables were significant in the same direction. As we are interested in exploring the possible influence of professional background we report the model with this variable included.

11 In a case revolving around whether a black, woman trial judge showed "apprehension of bias" when she accepted the testimony of an accused (black) youth over a police officer, two Canadian Supreme Court judges in a concurring opinion seemingly endorsed the latter perspective. "The sound belief behind the encouragement of greater diversity in judicial appointments was that women and visible minorities would bring an important perspective to the difficult task of judging" (R. v. S. (R.D.), 1997 at para 119). Also see the debate over the nomination of US Supreme Court Justice Sonia Sotomayor. 


\section{References}

Beiner, Theresa. M. 2002. "The Elusive (but Worthwhile) Quest for a Diverse Bench in the New Millennium." University of California Davis Law Review 36: 597-617.

Blake, Donald. 1988. "Division and Cohesion: The Major Parties." In Party Democracy in Canada: The Politics of National Party Conventions, ed. George Perlin. Scarborough ON: Prentice-Hall.

Boyd, Christina L., Lee Epstein and Andrew D. Martin. 2010. "Untangling the Causal Effects of Sex on Judging." American Journal of Political Science 54: 389-411.

Cross, Frank B. 2007. Decision-Making in the U.S. Court of Appeals. Palo Alto: Stanford University Press.

Farhang, Sean and Gregory Wawro. 2004. "Institutional Dynamics on U.S. Court of Appeals: Minority Representation under Panel Decision Making." Journal of Law, Economics and Organization 20: 299-330.

Flemming, Roy B. 2004. Tournament of Appeals: Granting Judicial Review in Canada. Vancouver: UBC Press.

Frank, James, Francis T. Cullen and John B. Cullen. 1987. "Sources of judicial attitudes toward criminal sanctioning." American Journal of Criminal Justice 11: 151-64.

Gidengil, Elisabeth, Matthew Hennigar, Andre Blais and Neil Nevitte. 2005. "Explaining the Gender Gap in Support of the New Right: The Case of Canada." Comparative Political Studies 38(10): 1171-95.

Gilligan, Carol. 1982. In a Different Voice: Psychological Theory and Women's Development. Cambridge: Harvard University Press.

Greene, Ian, Carl Baar, Peter McCormick, George Szablowski and Martin Thomas. 1998. Final Appeal: Decision Making in Canadian Courts of Appeal. Toronto: James Lorimar.

Hausegger, Lori, Troy Riddell, Matthew Hennigar and Emmanuelle Richez. 2010. "Exploring the Links between Party and Appointment: Canadian Federal Judicial Appointments from 1989 to 2003." Canadian Journal of Political Science 43: 633-59.

Johnson, Brian D. 2006. "The Multilevel Context of Criminal Sentencing: Integrating Judgeand County-level Influences." Criminology 44: 259-98.

Johnson, Susan and Donald Songer. 2009. "Judge Gender and the Voting Behavior of Justices on Two North American Supreme Court." The Justice System Journal 30: 265-79.

Johnson, Susan, Donald Songer and Nadia Jilani. 2011. "Judge Gender, Critical Mass, and Decision Making in the Appellate Courts of Canada." Journal of Women, Politics and Policy 32: 237-60.

Johnston, Richard. 1988. “The Ideological Structure of Opinion on Policy.” In Party Democracy in Canada: The Politics of National Party Conventions, ed. George Perlin. Scarborough ON: Prentice-Hall.

Malleson, Kate. 2003. "Justifying Gender Equality on the Bench: Why Difference Won't Do." Feminist Legal Studies 11: 1-24.

Massie, Tajuana, Susan W. Johnson and Sara Margaret Green. 2002. "The Impact of Gender and Race in the Decisions of Judges on the United States Courts of Appeal." Paper presented at the annual meeting of the Midwest Political Science Association, Chicago.

McCormick, Peter. 1993. "Party Capability Theory and Appellate Success in the Supreme Court of Canada, 1949-1992." Canadian Journal of Political Science 26: 523-40.

Meek, Jim. 1998. "Justice Heather Robertson: 'Not Recommended." Halifax ChronicleHerald, July 14, B1.

Ornstein, M.D. and H.M. Stevenson. 1984. "Ideology and Public Policy in Canada." British Journal of Political Science 14: 313-44.

Ostberg, C.L. and Matthew Wetstein. 2007. Attitudinal Decision Making in the Supreme Court of Canada. Vancouver: UBC Press.

Peresie, Jennifer L. 2005. "Female Judges Matter: Gender and Collegial Decision Making in the Federal Appellate Courts." Research note. Yale Law Journal 114: 1759. 
Riddell, Troy, Lori Hausegger and Matthew Hennigar. 2008. "Federal Judicial Appointments: A Look at Patronage in Federal Appointments since 1988." University of Toronto Law Journal 58: 39-74.

Schmitz, Christin. 2005. "Federal Judges Often Liberal Donors, Survey Finds." Ottawa Citizen, May 6, A5.

Schmitz, Christin. 2007. "Conservatives put more Crowns on the federal bench." Lawyers Weekly, February 9.

Sisk, Gregory C., Michael Heise and Andrew P. Morriss. 1998. "Charter the Influences on the Judicial Mind: An Empirical Study of Judicial Reasoning." New York University Law Review 73: 1377-1500.

Sniderman, Paul M., Joseph Fletcher, Peter Russell, Philip Tetlock and Markus Prior. 2000. "The Theory of Democratic Elitism Revisited: A Response to Vengroff and Morton." Canadian Journal of Political Science 33: 569-86.

Songer, Donald R. 2008. The Transformation of the Supreme Court of Canada: An Empirical Examination. Toronto: University of Toronto Press.

Songer, Donald R., Sue Davis and Susan Haire. 1994. "A Reappraisal of Diversification in the Federal Courts: Gender Effects in the Courts of Appeals." Journal of Politics 56: 425-39.

Songer, Donald, Reginald S. Sheehan and Susan B. Haire. 2000. Continuity and Change on the United States Courts of Appeals. Ann Arbor MI: University of Michigan Press.

Stribopoulos, James and Moin Yahya. 2007. "Does a Judge's Party of Appointment or Gender Matter to Case Outcomes? An Empirical Study of the Court of Appeal for Ontario." Osgoode Hall Law Journal 45: 315-64.

Sunstein, Cass R., David Schkade and Lisa Michelle Ellman. 2004. "Ideological Voting on Federal Courts of Appeals: A Preliminary Investigation." Virginia Law Review 90: 301.

Tarr, G. Alan. 2014. Judicial Process and Judicial Policy Making. 6th ed. Boston: Cengage.

Young, Lisa and William Cross. 2002. "Policy Attitudes of Party Members in Canada: Evidence of Ideological Politics.” Canadian Journal of Political Science 35: 859-80. 